\title{
Cefazaflur Sodium
}

National Cancer Institute

\section{Source}

National Cancer Institute. Cefazaflur Sodium. NCI Thesaurus. Code C81028.

The sodium salt form of cefazaflur, a semisynthetic first-generation cephalosporin with antibacterial activity. Cefazaflur binds to and inactivates penicillin-binding proteins (PBPs) located on the inner membrane of the bacterial cell wall. PBPs are enzymes involved in the terminal stages of assembling the bacterial cell wall and in reshaping the cell wall during growth and division. Inactivation of PBPs interferes with the cross-linkage of peptidoglycan chains necessary for bacterial cell wall streng th and rigidity. This results in the weakening of the bacterial cell wall and causes cell lysis. 